Dept. of Theriogenology,

Fac. of Vet. Med. Beni-Suef Cairo University.

\title{
EFFECT OF LEAD AND CADMIUM ON REPRODUCTIVE PERFORMANCE OF MALE RABBITS \\ (With 6 Tables)
}

\author{
By \\ E. M. ABD-ELGAWAD;E. A. MABROUK* \\ and M.A.M. KANDILE** \\ * Dept. of Physiology ** Dept. of Biochemistry \\ Fac. of Vet. Med. Beni-Suef Cairo Univ.
}

(Received at 16/3/1999)

تأثير الرصاص والكادميوم على الكفاعة التناسلية لذكور الأرانب

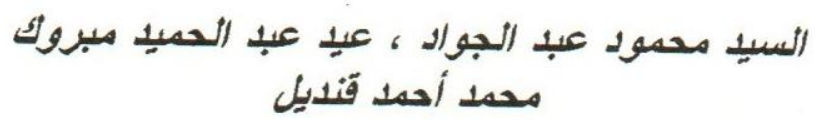

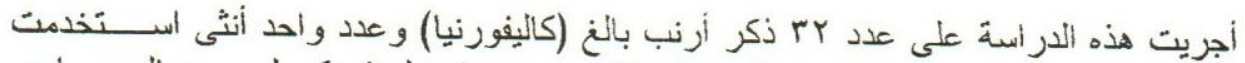

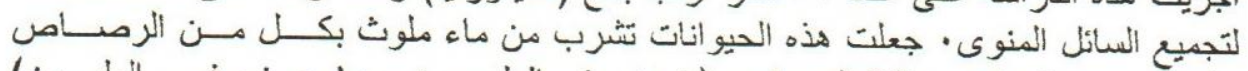

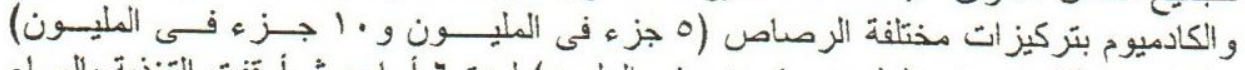

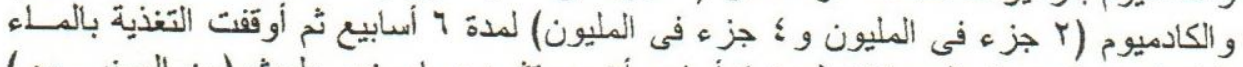

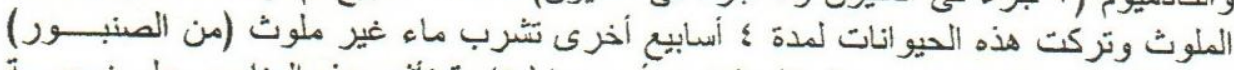

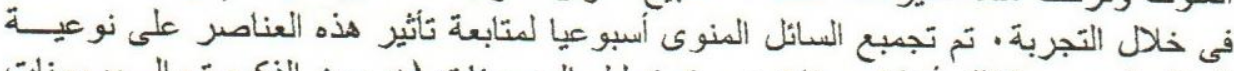

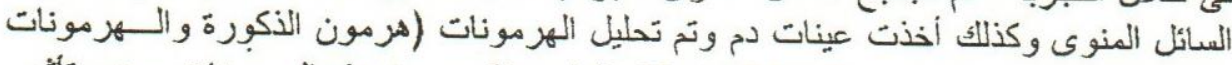

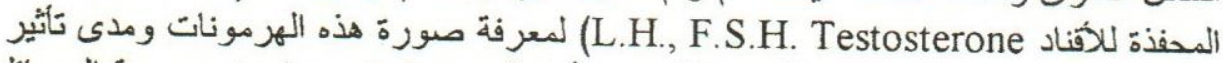

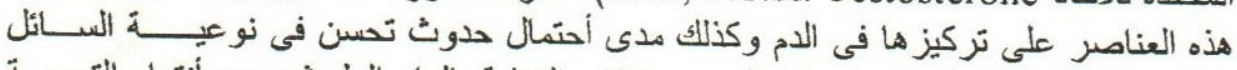

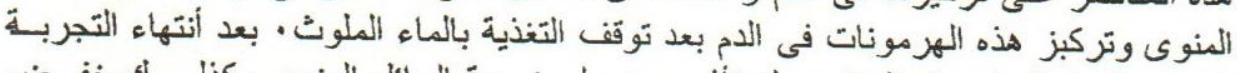

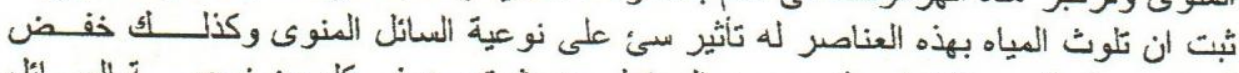

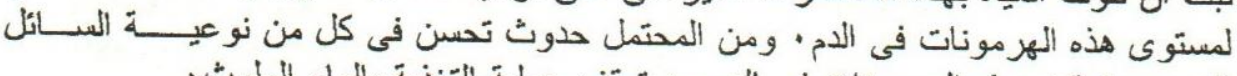

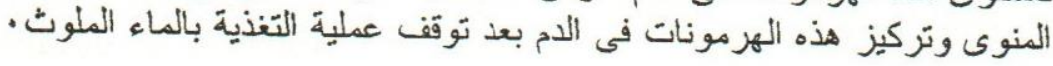

\section{SUMMARY}

A total of 32 adult male rabbits were used in this study. They were left for one month for training on semen collection and then classified into four groups ( 8 animals in each). The 1 st and 2 nd group were allowed to 
drink lead polluted water with low and high levels respectively $(5 \mathrm{ppm}$ $\& 10 \mathrm{ppm}$ ) while the $3 \mathrm{rd}$ and 4 th group were allowed to drink Cadmium polluted water with low and high level respectively ( $2 \mathrm{ppm} \& 4 \mathrm{ppm})$ for 6 weeks, then the treatments were stopped and the animals were allowed to drink pollution free water (normal tap water) for 4 weeks. Blood and semen samples were taken weekly before beginning, during and after stopping the treatments for evaluation of semen picture and analysis of testosterone, LH and F.S.H. hormones. The results showed that, the levels of testosterone, LH and F.S.H. hormones significantly decreased in treated animals and began to be significantly improved after stopping the treatment in both pollution levels of both elements. Also, the semen picture (volume, concentration, live/dead $\%$, motility $\%$, abnormalities) significantly decreased in treated animals starting from the $3 \mathrm{rd}$ week of treatment in case of low level of both elements and at the 2 nd week in case of high level of both elements. There were significant improvement in semen picture at the 4 th week post treatment when compared with that of the last week of treatment in all cases of pollution Both Cadmium and Lead pollutant are able to produce drastic effects on semen picture and reduction of hormonal levels, after stopping of pollution some improvement on semen picture and hormonal levels have occurred.

Key Words: Lead, Cadmium, Performance.

\section{INTRODUCTION}

The pollution of the environment with different sources is the vital talk allover the scientific media and the governmental and non governmental organization (N.G.O.). Thus cadmium and lead water pollution and its effects on reproductive capacity on different animals species has got great attention in different researches (Gabbiani et al, 1974, Suter-Ke, 1975 Aoki and Hoffer, 1978, Bryant and Rose, 1985, Alexaki and Tsafaris, 1991, Monsi, et al, 1993, and Ruby, et al, 1993) The recommended permissible level of cadmium in water is $10 \mathrm{Mg} / 1$ according to United States Environmental Protection Agency (1980)\# and $5 \mathrm{Mg} / \mathrm{l}$ according to the World Health Organization guidline values for drinking water quality (1984)\#.

The interpretation of the damage produced by cadmium and lead on the testis is not clearly identified but some suggestions and theories mentioned that the cadmium makes its effect on the vasculature of the testes, (Doh and Foster1972). Also Gazdik and Kaminski (1984) recomended that the cadmium and other metals can activate calmodulin 
(calcium-binding protein) which make disturbances in normal calcium control mechanism and by turn induced the toxiciy of the metal. These results were supported by Shore, et al (1995), Moreover, Gunn and Gould (1970) discussed a theory \# that cadmium caused a disruption of tight junction associated with microflaments in rat Sertoli cell. \# cited by Fayed and Abdallah 1997.

\section{MATERIAL and METHODS}

\section{Animals preparation:}

Thirty two male adult rabbits (Californian) of an average weight $4 \mathrm{~kg}$ were used in this experiment. Adult female were used in semen collection (as a teaser). These animals were kept in healthy, air refreshed room inside well prepared cages. Animal care including nutrition,watering health inspection were done with great attention. Eight males were used for each treatment. The animals were put under training program for semen collection for one month before the beginning of the experiment in a rate of twice a week, Each animal was kept in a separate cage.

\section{Semen collection:}

The semen was collected using artificial vagina for rabbits according to the method described by salisbury et al (1985).

\section{Chemicals and its preparation:}

Two heavy metals have been chosen, cadmium and lead in two successive concentrations from each. Tow concentrations of lead acetate were prepared. A low concentration, which is $5 \mathrm{ppm}$ and the high concentration is $10 \mathrm{ppm}$ dissolved in distilled water. Similarly two concentrations of cadmium chloride were prepared 1st is $2 \mathrm{ppm}$ (low concentration) and the 2 nd (high concentration) was $4 \mathrm{ppm}$ in distilled water.

\section{Watering of the animals:}

The animals were classified into 4 groups, 8 male animals in each group. The 1 st and 2 nd groups were allowed to drink day and night lead polluted water (low and high concentration respectively) and the 3 rd and 4 th groups were allowed to drink day and night cadmium polluted water (low and high concentration respectively) for 6 weeks. The males of each treatment were allowed to drink normal water for four weeks. Through this period regular semen collection was carried out to follow up the changes in semen picture (according to Salisbury et $\underline{\text { al, }}$ 1985) 


\section{Hormonal evaluation:}

Blood samples were collected before, (before starting the treatment), during, (at the 6th week from the beginning of the treatment period), and after treatment, (4th week after treatment) using sterile disposable syringe through jugular puncture. Serum was obtaind and preserved in deep freezer at $\left(-20^{\circ} \mathrm{C}\right)$ for hormonal analysis. Gonadotropine hormones according to ELISA Voller, et al, (1979), in this respect, F.S.H. (gestyl, Nile drug company) and L.H., (pregnyl, Nile drug company) were used as antigen to prepare their corresponding rabbit anti sera Testosterone using radio-imunoassay adopted by Vermuelen, and Verdonck, (1976) Statistical analysis was done according to Snedecor and Cochran (1980)

\section{RESULTS}

The results are presented in Tables 1,2,3,4,5 and, 6. Table 1 shows hormonal analysis of lead $1(5 \mathrm{ppm})$ and lead $2(10 \mathrm{ppm})$ treated animals. The data cleared that the levels of the three hormones ( $\mathrm{LH}$ \&F.S.H. and testosterone) were significantly reduced in treated animals and began to be significantly improved after stopping of treatment in both pollution levels of both elements (tables 1,2). Tables 3,4,5 and, 6 illustrate the semen picture of the animals drank polluted water with lead and cadmium. The data cleared that the semen picture began to significantly affected (decreased motility $\% \&$ sperm cell concentration and increased dead $\% \&$ abnormalities $\%$ ), from the $3 \mathrm{rd}$ week of treatments in animals kept to drink polluted water with low level of both elements and from the 2 nd week in animals drank polluted water with high level of both elements. Also the data cleared that there were significant improvement in semen picture at the 4 th week post-treatment when compared with that of the last week of treatment ( 6 th week) in all cases of pollution.

\section{DISCUSSION}

The obtained results of semen picture, revealed the drastic effect of treatment by both cadmium and lead treatments and control is very clear tables 3,4,5,6. and these results agree with Zavos and Cohen (1980) and Hew, et al (1993), However the results obtained by Monsi, et $\underline{\text { al }}$ (1993) on turkey differed with obtained results. This disagreement may due to species used (turkey) and route of injection (subcutaneous). Ruby, 
jaroslawsi, and Hull (1993) recorded that lead toxicity on the rainbow lead to drastic effect on semen picture and these results agreed with our results. Also the results obtained on bull revealed drastic effect on semen picture of bulls due to lead toxicity, Mankiewicz, et al (1975), similarly the obtained results in lead treatment was in accordance with those results obtained by Jaczewski, et al (1977) who reported that lead toxicity significantly reduced sperm cell concentration, sperm cell survival time in male rabbit.

These clearly identified deteriorating picture of semen in our results could be considered as an evidence of the damage effect on the seminiferous tubules these results agreed with Fayed and Abdalla (1997) who recorded that toxicity of male rats with cadmium chloride lead to degeneration in seminiferous tubules. Also the results agreed with Gunn and Gould (1970) who reported that cadmium toxicity in rat lead to degeneration in seminiferous tubules. In addition Ruby, et al (1993) recorded that the lead toxicity in rainbow suppress the spermatogenesis by acting on sublethal level on the cycle. These result appeared in accordance with our results.

The obtained results point out that there are reduction in both testosterone, L.H. and F.S.H. in comparison with control readings, (Tables 1,2). The available literature concerning the effect of cadmium and lead on the level of these hormones are very scarce. These results appeared in accordance with those obtained by Kuo, et al (1995) that the L.H \&F.S.H. \& testosterone are significantly reduced .In mice fertility and libido were lost after treatment with cadmium $5 \mathrm{mg} / \mathrm{kgr}$ and $2 \mathrm{mg} / \mathrm{kgr}$ body weight thus may be the effect of these heavy metals on the vascularity of the testis and the Leydig cells. Doh and Foster (1972), Gabbiani, et al (1974) Aoki and Hoffer (1978).

Unfortunately the recovery result which have been obtained in both semen picture and hormonal level, a little references were available. Thus after stopping of treatment there are some improvement in semen characters and libido also hormonal level. These results agreed with Kuo, et al (1995), who claimed that the L.H \&F.S.H. \& testosterone are significantly reduced and the infertility and libido were lost in mice treated with cadmium and recovered again after 6 weeks from stopping of treatment.

According to the results obtained in this study pollution with both lead (5pm \& 10ppm) and cadmium ( $2 \mathrm{ppm} \& 4 \mathrm{ppm})$ adversly affected fertility and libido which is a warning from pollution with both metals. 


\section{REFERENECES}

Alexaki-E, and Tsafaris -F, (1991): "Effect of age on the seminal and spermatozoa lead concentrations of bull". Veterinary -and Human toxocology, 33:2,128-130,17 ref.

Aoki, A. and Hoffer, A.P., (1978): "Re examination of the lesions in rat testis caused by cadmium "Biol. Reprod., 18,579

Bryant-SL and Rose-RW, (1985): "Effect of cadmium on the reproductive organs of the male potorous tridactylus (Macropodidae) "Australian -Journal -of -Biological-sciences, 28,3,305-311,15ref.

Doh, H.M. and Foster, G.C., (1972): "Technique for studying the morphology of mammalian spermatozoa wich are eosinophilic in a different live/dead stain. J. Reprod. Fertil, 29,443.

Fayed A.H. and Abdallah E.B., (1997): "Effect of cadmium chloride on some reproductive aspect in adult male rats "Ninth Anual Congress of Egyptian Soc. Anim.Reprod, Fert.,61-68

Gabbiani, G,B, Marie,. shella, M. Malhewson, M.B.and Graeme, B.R, (1974): Acute cadmium intoxication, early selective lesions of endothelial cells Lab Inves, 30:686

Gazdik, T. and Kaminski, M., (1984): Ultrastructural study of development of the rat tesis. II.After injecting $\mathrm{Cd} \mathrm{cl} 2$, Folia Morphol.,32,218.

Gunn, S.A., and Gould T.C., (1970): Specificity of the vasculature system of the male reproductive tract J. Reprod. Fertil., 10:75

Hew, K.W., Heath, G.L, Jiwa A.H. and. Welsh, M.J, (1993): Cadmium in vivo causes disruption of tight junction associated microfilaments in rat Sertoli cells. Biol. Reprod., 49:840

Jaczewski-S, Dynarowicz -I and Monkiewiecz -J, (1977): The effect of long -term administration of copper and lead- containing substances to rabbits on semen characters. Medycyna Weterynaryjna, 33.7,410-412.

Kuo -TF, Chang - CH and Lau-CF, (1995): Effects of cadmium on the libido and fertility of male mice. Journal of the chinese-society of veterinary-science., 21:1,1-11,17 ref.

Mankiewicz, -J, Jaczewski-S and Dynarowicz -I, (1975): Heavy metal content of the semen of bulls from various environments Medycyna -Weterynaryjna, 31,11, 684-686. 
Monsi - A, Cecil-HC and Bakst -MR, (1993): Aspects of biological changes in breeder toms. after treatment with subcutaneous cadmium injection study of some semen characteristics. Journal of Applied -Animal -Researche, 4:2,83-90,29 ref.

Ruby-SM, Jaroslawsi -P, and Hull-R, (1993): Lead and cyanide toxicity in sexually maturing raibow trout, toxicity in sexually maturing rainbow trout, oncorhynchus mykiss during spermatogenesis. Aquatic -Toxocology, 26,3-4, 225-238, 33 ref.

Salisbury, G.W.\&Van Demark, N.L. and Lodge .J. R., (1985): "Physiology of Reproduction and Artificial Insemination of cattle W.H. Freeman, San Francisco

Shore, R.F., Myhill, D.G., Routtedge E.J and. Wilby, A., (1995): Impact of an environmentally -realistic intake of cadmium on calcium, magnesium and phsphate metabolism in bank voles clethrionmys glareous. Arch, Environ. ctamin. Toxical, 29:180.

Snedecor, G.W.and Cochran, W.G. (1980): Statistical Methods. 7th ed., the Iowa state univ. Press, Ames Iowa.

Suter-Ke, (1975): Studies on the dominant -lethal and fertility effects of the heavy metal compounds, methyl mercuric hydroxide, mercuric chloride inand cadmium chloride in male and female mice. Mutation research, 30:3,365-374.

Vermuelen, A. and Verdonck, J. (1976): Radioimunoassay 17-Bhydroxy, 4,5, ostone and 17 Dian - dehydrobiandrosterone, 17 hydroxy, progesterone and its application to human male plasma. J. of steroid biochemistry, 7,1-10.

Voller A., Bidwell D.E. and Bartlett A. (1979): The Enzyme Linked Immunosorbant Assay (ELISA). The Zoological Society of London, pp:16-17

Zavos, PM., and Cohen, M.R., (1980): The $\mathrm{pH}$ of the cervical mucus and the postcoital test. Fertil.Steril., 34;234 
Table 1: Levels of L.H., F.S.H. and Testosterone in male rabbits drunk polluted water with both levels of lead acetate.

Lead

\begin{tabular}{|c|c|c|c|c|c|c|}
\hline \multirow[b]{2}{*}{ Group } & \multicolumn{3}{|c|}{$5 \mathrm{ppm}$} & \multicolumn{3}{|c|}{10 ppm } \\
\hline & $\begin{array}{c}\text { L.H } \\
\text { i.u. } / \mathrm{ml}\end{array}$ & $\begin{array}{c}\text { F.S.H } \\
\text { i.u. } / \mathrm{ml}\end{array}$ & $\begin{array}{c}\text { Testosterone } \\
\mathrm{ng} / \mathrm{ml}\end{array}$ & $\begin{array}{c}\text { L.H } \\
\text { i.u. } / \mathrm{ml}\end{array}$ & $\begin{array}{l}\text { F.S.H } \\
\text { i.u. } / \mathrm{ml}\end{array}$ & $\begin{array}{c}\text { Testosterone } \\
\mathrm{ng} / \mathrm{ml}\end{array}$ \\
\hline Control & $\begin{array}{r}3.17 \\
+0.44\end{array}$ & $\begin{array}{r}2.78 \\
+0.26\end{array}$ & $\begin{array}{c}4.75 \\
\pm 0.51\end{array}$ & $\begin{array}{r}3.17 \\
+0.44\end{array}$ & $\begin{array}{r}2.78 \\
\pm 0.26\end{array}$ & $\begin{array}{r}3.17 \\
+0.5\end{array}$ \\
\hline Treated & $\begin{array}{r}\mathrm{ab}{ }^{1.05} \\
+0.35\end{array}$ & $\begin{aligned} & a b \\
& 1.017 \\
+ & 0.29\end{aligned}$ & $\begin{array}{l}1.98 \\
+0.15\end{array}$ & $\begin{array}{r}\text { bc } \\
0.99 \\
\pm 0.09\end{array}$ & $\begin{array}{r}1.12^{\text {ba }} \\
\pm 0.21\end{array}$ & $\begin{array}{l}1.59 \\
1 \mathrm{db} \\
\pm 0.17\end{array}$ \\
\hline $\begin{array}{c}\text { Post. } \\
\text { Treated }\end{array}$ & $\begin{array}{r}\text { ba } \\
2.64 \\
\pm 0.51\end{array}$ & $\begin{array}{r}2.13^{\mathrm{a}} \\
\pm 0.32\end{array}$ & $\begin{array}{r}3.65 \\
\pm 0.49\end{array}$ & $\begin{array}{r}2.52^{c} \\
\pm 0.33\end{array}$ & $\begin{array}{r}2.18 \\
\pm 0.23\end{array}$ & 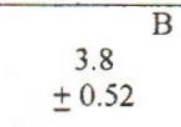 \\
\hline
\end{tabular}

Within the same column values having the same letter differ significantly at :a $(p(0.05), b$ and $c:(p(0.01)$ and $d:$ at $(p(0.001)$

Table 2: Levels of L.H., F.S.H. and Testosterone in male rabbits drunk polluted water with both levels of Cadmium chloride.

\begin{tabular}{|c|c|c|c|c|c|c|}
\hline \multicolumn{7}{|c|}{ Cadmium } \\
\hline \multirow[b]{2}{*}{ Group } & \multicolumn{3}{|c|}{$2 \mathrm{ppm}$} & \multicolumn{3}{|c|}{4 ppm. } \\
\hline & $\begin{array}{l}\text { L.H. } \\
\text { i.u./mI }\end{array}$ & $\frac{\text { F.S.H. }}{\text { i.u./ml }}$ & $\frac{\text { Testosterone }}{\text { n.g/ml }}$ & L.H. & $\frac{\text { F.S.H }}{\text { i.u. } / \mathrm{ml}}$ & $\frac{\text { Testosterone }}{\text { n.g } / \mathrm{ml}}$ \\
\hline Control & $\begin{array}{r}3.17 \\
\pm 0.44\end{array}$ & $\begin{array}{r}2.78^{c} \\
\pm 0.26\end{array}$ & $\begin{array}{c}4.75 \\
\pm 0.51\end{array}$ & $\begin{array}{r}3.17 \\
\pm 0.44\end{array}$ & $\begin{array}{c}2.78 \\
\pm 0.26\end{array}$ & $\begin{array}{r}4.75 \\
\pm 0.51\end{array}$ \\
\hline Treated & $\begin{array}{r}1.01 \\
\pm 0.12 \\
\end{array}$ & $\begin{array}{c}\text { cd } \\
0.75 \\
\pm 0.11 \\
\end{array}$ & $\begin{array}{r}1.45 \\
\pm 0.16 \\
\end{array}$ & $\begin{array}{r}\text { ac } \\
0.88^{\text {ac }} \\
\pm 0.11 \\
\end{array}$ & $\begin{array}{l}0.66^{\mathrm{cd}} \\
\pm 0.10 \\
\end{array}$ & $\begin{array}{l}1.44 \\
\pm 0.15 \\
\end{array}$ \\
\hline $\begin{array}{l}\text { Post- } \\
\text { treated }\end{array}$ & $\begin{array}{r}2 \mathrm{~b} \\
2.22 \\
\pm 0.19\end{array}$ & $\begin{array}{r}\text { d } \\
2.01 \\
\pm 0.15\end{array}$ & $\begin{array}{c}3.98 \\
\pm 0.56\end{array}$ & $\begin{array}{r}2.44 \\
\pm 0.22\end{array}$ & $\begin{array}{r}2.18^{d} \\
\pm 0.20\end{array}$ & $\begin{array}{c}3.87 \\
\pm 0.55\end{array}$ \\
\hline
\end{tabular}

Within the same column values having the same letter differ significantly at a and $b:(p(0.01)$ and $c$ and $d:$ at $(p(0.001)$ 
Table 3: The results of semen characters of male rabbits of both, control, (pretreatment) and during treatment with low and high levels of Lead acetate.

Semen characters of lead 1 treated animals $(5 \mathrm{ppm})$

\begin{tabular}{|c|c|c|c|c|c|}
\hline $\begin{array}{l}\text { Characters/ } \\
\text { treatments }\end{array}$ & $\frac{{ }^{*}}{(\mathrm{ml})}$ & $\frac{\text { Motility }}{(\%)}$ & $\frac{\text { Dead }}{(\%)}$ & $\frac{\text { Concentration }}{\mathrm{X} 10^{6}(\mathrm{ml})}$ & $\frac{\text { Abnormalities }^{* *}}{(\%)}$ \\
\hline Control & $0.72 \pm 0.007$ & $\begin{array}{r}\text { bc } \\
74.5 \pm 1.167\end{array}$ & $\begin{array}{r}\text { abc } \\
8.5 \pm 0.5\end{array}$ & $188.0 \pm 2.49^{b c}$ & $9.2 \pm 0.44$ \\
\hline 1st Weak & $0.74 \pm 0.026$ & $73.75 \pm 2.39$ & $11.75 \pm 2.32$ & $180 \pm 19.7$ & $11.0 \pm 4.05$ \\
\hline 2nd Weak & $0.73 \pm 0.012$ & $71.25 \pm 2.39$ & $13.0 \pm 2.517$ & $169 . \pm 15.3$ & $13.0 \pm 2.17$ \\
\hline 3rd Weak & $0.718 \pm .012$ & $\begin{array}{r}b \\
65.0 \pm 2.041 \\
\end{array}$ & $\begin{array}{r}\mathrm{a} \\
15.0 \pm 2.11 \\
\end{array}$ & $\begin{array}{r}c \\
150.0 \pm 4.08 \\
\end{array}$ & $\begin{array}{r}\mathrm{c} \\
20.0 \pm 2.04 \\
\end{array}$ \\
\hline 4th Weak & $0.718 \pm 0.024$ & $\begin{array}{r}c \\
55.0 \pm 3.146 \\
\end{array}$ & $\begin{array}{r}c \\
22.5 \pm 2.5 \\
\end{array}$ & $\begin{array}{r}c \\
135.0 \pm 8.66 \\
\end{array}$ & $\begin{array}{r}\mathrm{c} \\
26.5 \pm 3.15 \\
\end{array}$ \\
\hline 5th Weak & $0.73 \pm 0.012$ & $\begin{array}{r}c \\
47.5 \pm 4.787 \\
\end{array}$ & $\begin{array}{r}\mathrm{c} \\
30.0+2.887 \\
\end{array}$ & $\begin{array}{r}\mathrm{c} \\
102.5 \pm 8.5 \\
\end{array}$ & $\begin{array}{r}\mathrm{c} \\
31.5 \pm 1.25 \\
\end{array}$ \\
\hline 6th Weak & $0.735 \pm 0.009$ & $\begin{array}{r}c d \\
30.0 \pm 4.082\end{array}$ & $\begin{array}{r}c d \\
31.25 \pm 2.39\end{array}$ & $\begin{array}{r}c d \\
70.0 \pm 8.16\end{array}$ & $\begin{array}{r}c d \\
37.5 \pm 1.44\end{array}$ \\
\hline $\begin{array}{c}\text { 1st Weak } \\
\text { post- } \\
\text { treatment }\end{array}$ & $0.735 \pm 0.009$ & $\begin{array}{r}c \\
33.5 \pm 2.394\end{array}$ & $\begin{array}{r}\mathrm{c} \\
31.25 \pm 2.39\end{array}$ & $\begin{array}{r}c \\
82.5 \pm 2.5\end{array}$ & $\begin{array}{r}\mathrm{c} \\
25.0 \pm 2.04\end{array}$ \\
\hline $\begin{array}{c}\text { 2ndWeak } \\
\text { post- } \\
\text { treatment }\end{array}$ & $0.743 \pm 0.008$ & $\begin{array}{r}c \\
38.75 \pm 2.39\end{array}$ & $26.25 \pm 1.25$ & $\begin{array}{r}c \\
102.5 \pm 2.5\end{array}$ & $23.5 \pm 2.39$ \\
\hline $\begin{array}{c}\text { 3rd Weak } \\
\text { post- } \\
\text { treatment }\end{array}$ & $0.730 \pm 0.009$ & $\begin{array}{r}c \\
56.25 \pm 2.39\end{array}$ & $\begin{array}{r}b \\
18.75 \pm 2.39\end{array}$ & $\begin{array}{r}b \\
127.5 \pm 11.09\end{array}$ & $22.5 \pm 1.44$ \\
\hline $\begin{array}{c}\text { 4th Weak } \\
\text { post- } \\
\text { treatment }\end{array}$ & $0.715 \pm 0.012$ & $\begin{array}{r}d \\
67.5 \pm 3.22\end{array}$ & $\begin{array}{r}d \\
10.5 \pm 1.44\end{array}$ & $162.5 \pm 10.5$ & $\begin{array}{r}d \\
13.25 \pm 2.39\end{array}$ \\
\hline
\end{tabular}

Within the same column values having the same letter differ significantly at a : $(p(0.05)$, b: at $(p(0.01)$ and $c$ :at $(p(0.001)$ Values of the fourth week post treatment are significantly different from that of the six week of the treatment at $p(0.001$ in case of $d)$. * The total volume ** Primary abnormalities. 
Table 4: Semen characters of lead 2 treated animals (10 ppm)

\begin{tabular}{|c|c|c|c|c|c|}
\hline $\begin{array}{c}\text { Characters } \\
\text { / Control }\end{array}$ & $\begin{array}{c}{ }^{\star} \\
\frac{\text { Volume }}{(\mathrm{ml})}\end{array}$ & $\frac{\text { Motility }}{(\%)}$ & $\frac{\text { Dead }}{(\%)}$ & $\frac{\text { Concentration }}{\mathrm{X} 10^{6}(\mathrm{ml})}$ & $\begin{array}{c}{ }^{* *} \\
\frac{\text { Abnormaliti }}{\underline{\text { es }}} \\
(\%)\end{array}$ \\
\hline Control & $0.72 \pm 0.006$ & $\begin{array}{r}a b c \\
74.5 \pm 1.84\end{array}$ & $\begin{array}{r}a b c \\
8.4 \pm 0.27\end{array}$ & $\begin{array}{r}a b c \\
188 . \pm 3.59\end{array}$ & $\begin{array}{r}\mathrm{ac} \\
9.9 \pm 0.67\end{array}$ \\
\hline 1stWeak & $0.73 \pm 0.01$ & $71.25 \pm 1.25$ & $9.0 \pm 0.58$ & $173.0 \pm 16.0$ & $10.0 \pm 2.86$ \\
\hline 2ndWeak & $0.75 \pm .02$ & $67.5 \pm 1.44^{\mathrm{a}}$ & $13.75 \pm 1.25^{b}$ & $150.0 \pm 11.5$ & $\begin{array}{c}c \\
12.75 \pm 2.29\end{array}$ \\
\hline 3rdWeak & $0.71 \pm 0.014$ & $61.25 \pm 1.25^{c}$ & $17.5 \pm 1.44^{c}$ & $120.5 \pm 9.74$ & $18.75 \pm 1.25^{\mathrm{c}}$ \\
\hline $4^{\text {th }}$ Weak & $0.74 \pm 0.03$ & $53.75 \pm 1.25^{c}$ & $21.25 \pm 1.25^{c}$ & $95.0 \pm 2.89 \quad \mathrm{c}$ & $23.75 \pm 1.25^{c}$ \\
\hline 5thWeak & $0.73 \pm 0.014$ & $46.25 \pm 2.39^{c}$ & $28.75 \pm 1.25^{c}$ & $72.5 \pm 8.54$ & $31.25 \pm 3.75^{\mathrm{c}}$ \\
\hline 6thWeak & $0.68 \pm 0.013$ & $\begin{array}{r}\text { cd } \\
28.75 \pm 3.15\end{array}$ & $41.25 \pm 1.25$ & $67.5 \pm 6.29{ }^{\mathrm{cd}}$ & $40.0 \pm 2.02^{c d}$ \\
\hline $\begin{array}{c}\text { 1stWeak } \\
\text { post- } \\
\text { treatment }\end{array}$ & $0.70 . \pm 0.01$ & $22.5 \pm 2.5^{c}$ & $28.75 \pm 1.45^{c}$ & $80 . \pm 07.12$ & $37.5 \pm 1.44^{c}$ \\
\hline $\begin{array}{c}\text { 2ndWeak } \\
\text { post- } \\
\text { treatment }\end{array}$ & $0.72(0.014$ & $28.75 \pm 3.15^{c}$ & $22.5 \pm 2.5^{b}$ & $102.5 \pm 7.5$ & $28.5 \pm 3.75$ \\
\hline $\begin{array}{c}\text { 3rdWeak } \\
\text { post- } \\
\text { treatment }\end{array}$ & $0.71 \pm 0.035$ & $47.5 \pm 4.79^{c}$ & $18.75 \pm 2.25^{b}$ & $122.5 \pm 5.79^{c}$ & $21.25 \pm 2.39^{c}$ \\
\hline $\begin{array}{l}\text { 4th Week } \\
\text { post- }\end{array}$ & $0.68 \pm 0.043$ & $63.9 \pm 3.7^{\text {bd }}$ & $\begin{array}{c}\mathrm{ad} \\
15.5 \pm 1.99\end{array}$ & $145.5 \pm 8.87 .{ }^{\text {bd }}$ & $16.0 \pm 1.94^{\text {ad }}$ \\
\hline
\end{tabular}

Within the same column values having the same letter differ significantly at a: ( $p$ $(0.05)$, b: at (p (0.01) and $c$ :at (p (0.001) Values of the fourth week post treatment are significantly different from that of the six week of the treatment at $p(0.001$ in case of $\mathrm{d})$. * The total volume ${ }^{* *}$ Primary abnormalities. 
Table 5: The results of semen characters of male rabbits of both, control, (pretreatment) and during treatment with low and high levels of Cadmium chloride.

Semen characters of Cadmium 1 treated animals (2 ppm)

\begin{tabular}{|c|c|c|c|c|c|}
\hline $\begin{array}{l}\text { Treatments } \\
\text { /characters }\end{array}$ & $\frac{\text { Volume }}{(\mathrm{ml})}$ & $\frac{\text { Motility }}{(\%)}$ & $\frac{\text { Dead }}{(\%)}$ & $\frac{\text { Concentration }}{\times 10^{6}(\mathrm{ml})}$ & $\begin{array}{c}* * \\
\text { Abnormaliti } \\
\frac{\text { es }}{(\%)}\end{array}$ \\
\hline Control & $0.742 \pm 0.009$ & $75.0 \pm 1.29^{\mathrm{c}}$ & $8.8 \pm 0.33^{b c}$ & $204.0 \pm 3.16^{\mathrm{bc}}$ & $9.8 \pm 0.36^{a b c}$ \\
\hline Ist Week & $0.731 \pm 0.033$ & $75.0 \pm 2.04$ & $9.25 \pm 1.11$ & $202.5 \pm 8.54$ & $10.5 \pm 2.4$ \\
\hline $2^{\text {nd }}$ Week & $0.729 \pm 0.021$ & $75.75 \pm 2.17$ & $9.75 \pm 0.85$ & $202.5 \pm 6.61$ & $10.75 \pm 1.11$ \\
\hline 3rd Week & $0713 \pm 0.015$ & $67.5 \pm 3.23$ & $13.0 \pm 1.22$ & $189.3 \pm 1.49$ & $12.5 \pm 1.04$ \\
\hline 4th Week & $0.710 \pm 0.018$ & $56.75 \pm 2.69$ & $17.5 \pm 1.99$ & $150.0 \pm 4.08$ & $23.75 \pm 1.25$ \\
\hline 5th Week & $0.725 \pm 0.01$ & $42.5 \pm 3.23$ & $23.25 \pm 2.69$ & $111.3 \pm 6.57$ & $32.25 \pm 1.03$ \\
\hline 6th Week & $0.70 \pm 0.022$ & no sperms & no sperms & no sperms $\quad \mathrm{c}$ & no sperms \\
\hline $\begin{array}{l}\text { 1st Week } \\
\text { post- } \\
\text { treatment }\end{array}$ & $0.712 \pm 0.022$ & no sperms & no sperms & no sperms & no sperms \\
\hline $\begin{array}{l}2^{\text {nd }} \quad \text { Week } \\
\text { post- } \\
\text { treatment }\end{array}$ & $0.715 \pm 0.024$ & no sperms & no sperms & no sperms & no sperms \\
\hline $\begin{array}{l}\text { 3rd Week } \\
\text { post- } \\
\text { treatment }\end{array}$ & $0.731 \pm 0.017$ & $40.5 \pm 3.23^{c}$ & $31.75 \pm 1.18^{\mathrm{c}}$ & $72.5 \pm 7.5 \quad$ c & $26.25 \pm 3.15^{b}$ \\
\hline $\begin{array}{l}\text { 4th Week } \\
\text { post- } \\
\text { treatment }\end{array}$ & $0.735 \pm 0.014$ & $72.0 \pm 3.17^{d}$ & $13.0 \pm 2.04^{\mathrm{d}}$ & $190.0 \pm 8.57^{d}$ & $12.5 \pm 3.23$ \\
\hline
\end{tabular}

Within the same column values having the same letter differ significantly at a: $(p(0.05), b$ : at $(p(0.01)$ and $c:$ at $(p(0.00)$ Values of the fourth week post treatment are significantly different from that of the six week of the treatment at $p(0.001$ in case of $d)$.

* The total volume ** Primary abnormalities. 
Table 6: semen characters of cadmium 2 treated animals (4 ppm)

\begin{tabular}{|c|c|c|c|c|c|}
\hline $\begin{array}{l}\text { /characters } \\
\text { treatments }\end{array}$ & $\frac{{ }^{\star}}{\text { Volume }}$ & $\frac{\text { Motility }}{(\%)}$ & $\frac{\text { Dead }}{(\%)}$ & $\frac{\text { Concentration }}{\times 10^{6}(\mathrm{ml})}$ & $\frac{{ }^{* *}}{\text { Abnormalities }}$ \\
\hline Control & $0.738 \pm 0.01$ & $72.5 \pm 1.34^{\text {bc }}$ & $9.2 \pm 0.44^{a b c}$ & $194.0 \pm 4.0 \quad$ ac & $10.4 \pm 0.5^{a b c}$ \\
\hline 1st Week & $0.720 \pm 0.027$ & $71.25 \pm 1.25$ & $11.25 \pm 1.49$ & $190.75 \pm 5.45$ & $10.25 \pm 1.65$ \\
\hline 2nd Week & $0.718 \pm 0.012$ & $67.5 \pm 3.23$ & $17.0 \pm 1.22^{\text {c }}$ & $170.0 \pm 11.5^{\mathrm{c}}$ & $11.75 \pm 1.18$ \\
\hline 3rd Week & $0.730 \pm 0.007$ & $45.0 \pm 2.04^{c}$ & $25.0 \pm 2.04^{c}$ & $130.0 \pm 3.39$ c & $20.75 \pm 2.53$ \\
\hline 4th Week & $0.743 \pm 0.022$ & $32.5 \pm 3.23^{c}$ & $41.25 \pm 3.15^{c}$ & $90.25 \pm 5.54 \quad c$ & $31.25 \pm 2.39$ \\
\hline 5th Week & $07513 \pm 0.022$ & $17.5 \pm 2.23^{c}$ & $42.5 \pm 3.23^{c}$ & $58.75 \pm 7.74$ & $47.0 \pm 3.39$ \\
\hline 6th Week & $0.725 \pm 0.01$ & no sperms & no sperms & no sperms & no sperms \\
\hline $\begin{array}{l}\text { Ist Weak } \\
\text { post- } \\
\text { treatment }\end{array}$ & $0.725 \pm 0.036$ & no sperms & no sperms & no sperms & no sperms \\
\hline $\begin{array}{l}\text { 2nd Weak } \\
\text { post- } \\
\text { treatment }\end{array}$ & $0.735 \pm 0.009$ & no sperms & no sperms & no sperms & no sperms \\
\hline $\begin{array}{l}\text { 3rd Weak } \\
\text { post- } \\
\text { treatment }\end{array}$ & $0.743 \pm 0.022$ & $43.75 \pm 6.25^{b}$ & $20.25 \pm 2.75^{b}$ & $57.5 \pm 7.22$ & $33.5 \pm 5.15$ \\
\hline $\begin{array}{l}\text { 4th Weak } \\
\text { post- } \\
\text { treatment }\end{array}$ & $0.725 \pm 0.014$ & $65.0 \pm 3.54^{d}$ & $15.5 \pm 2.5^{\text {ad }}$ & $137.0 \pm 15$ ad & $16.5 \pm 2.22$ ad \\
\hline
\end{tabular}

Within the same column values having the same letter differ significantly at a: $(p(0.05)$, b: at $(\mathrm{p}(0.01)$ and $\mathrm{c}$ : at $(\mathrm{p}(0.001)$ Values of the fourth week post treatment are significantly different from that of the six week of the treatment at p (0.001 in case of $\mathrm{d} .{ }^{*}$ The total volume ${ }^{*}$ Primary abnormalities. 